\title{
Silage of Marandu Grass with Levels of Stylo Legume Treated or Not with Microbial Inoculant
}

\author{
Joao P. S. Rigueira ${ }^{1}$, Odilon G. Pereira ${ }^{2}$, Karina G. Ribeiro ${ }^{2}$, Sebastião de C. V. Filho ${ }^{2}$, Andréia S. Cezário ${ }^{3}$, \\ Vanessa P. da Silva ${ }^{2} \&$ Mariele C. N. Agarussi \\ ${ }^{1}$ State University of Montes Claros, Janaúba, Montes Claros, Brazil \\ ${ }^{2}$ Federal University of Viçosa, Brazil \\ ${ }^{3}$ Instituto Federal Goiano, Brazil \\ Correspondence: Joao P. S. Rigueira, State University of Montes Claros, Janaúba, Brazil. E-mail: \\ jpzootecnia@hotmail.com
}

Received: May 9, 2017

Accepted: July 5, $2017 \quad$ Online Published: August 15, 2017

doi:10.5539/jas.v9n9p36

URL: https://doi.org/10.5539/jas.v9n9p36

This research had financial support by Fapemig and Capes.

\begin{abstract}
The chemical composition, fermentation profile, microbial population and dry matter recovery were evaluated in marandu grass silages containing different levels of Stylo legume cv. Campo Grande treated or not with microbial inoculant. A $4 \times 2$ factorial arrangement (four levels of Stylo legume, with and without microbial inoculant) was used in a completely randomized design with four replications. The levels of Stylo legume used were $0,10,20$ and $30 \%$ of the weight in the natural matter. The marandu grass was harvested at 70 days of regrowth and the Stylo legume at the pre-flowering stage. It was observed the effect of interaction between levels of Stylo legume and microbial inoculant on dry matter content, effluent losses, dry matter recovery and yeast and molds populations. The dry matter content of the silages with and without inoculant increased $(\mathrm{P}<0.05)$ linearly with the addition of Stylo legume. A linear decreasing effect was observed for neutral detergent fiber contents and a linear crescent effect for the crude protein contents of the silages with addition of Stylo legume. The $\mathrm{pH}$ values had a quadratic effect with addition of Stylo legume, with a maximum value of 4.16 in the inclusion of $12.25 \%$ of Stylo legume. The LAB population increased linearly with an increase in the levels of Stylo legume. The dry matter recovery increased linearly with the addition of Stylo legume, in the silages without inoculant. It is concluded that the consortium of marandu grass with Stylo legume improves the chemical composition, fermentation profile, and decrease the dry matter losses of the silages, regardless of the use of microbial inoculant.
\end{abstract}

Keywords: additive, Brachiaria brizantha, Stylosanthes ssp.

\section{Introduction}

Despite the large territory Brazilian pasture, it has been observed decrease in productivity, mainly caused by reduced soil fertility. The lack of nutrient replacement and/or inadequate management contributed for the degradation of an expressive area of pasture. Although it is recognized the importance of the nitrogen fertilization as a way to contain the process of degradation of pastures and ensure their persistence, the use of this nutrient is limited due to the high cost. As a viable alternative to maintain the soil fertility, the use of grass and legume consortium has deserved prominence, especially with those of the Stylosanthes genus (Paciullo, Aroeira, Alvim, \& Carvalho, 2003; Pariz et al., 2017).

Among the advantages of the consortium of grasses with legumes we can highlight the increase of nutritional value of the diet, improvement in animal production and the indirect effects related to the nitrogen contribution to the pasture ecosystem.

Although the high nutritious value, legumes generally have some inappropriate characteristics for proper fermentation process when exclusive ensiled, such as a high moisture content at the time of cutting, high buffering capacity, low levels of carbohydrates and hollow tubular stem, which difficult the complete removal of 
air at the ensile time (McAllister et al., 1998). It is believed that these problems can be minimized by ensiling mixed pastures, which can improve nutritional value of the feed and minimize fermentation losses. According to Santos et al. (2016) the use of microbial additives can improve the fermentation profile of the silages by the higher production of acids that lowers the $\mathrm{pH}$ rapidly, thus minimizing the fermentative losses. Considering the scarcity of information on mixed ensiling of grasses and legumes, the present study was conducted with the purpose of evaluating quality and losses of marandu grass (Brachiaria brizantha cv. Marandu) silages with different levels of Stylo legume inoculated or not with microbial additive. The levels of Stylo legume used are intended to simulate intercropped pastures containing low, medium and adequate rate of the legume in the pasture.

\section{Material and Methods}

The experiment was conducted in the Department of Animal Science of the Federal University of Viçosa, located in Viçosa-MG/Brazil. The city is located at $20^{\circ} 45^{\prime}$ south latitude, $42^{\circ} 51^{\prime}$ west longitude and $657 \mathrm{~m}$ altitude, presenting annual precipitation of $1.341 \mathrm{~mm}$, of which about $86 \%$ occur between October and March. It was used established pastures with monoculture of marandu grass (Brachiaria brizantha cv. Marandu) and Stylosanthes cv. Campo Grande. Before the beginning of the experiment, a cut of uniformity of the experimental area was made, using a costal brush. For marandu grass, it was made cover fertilization with $300 \mathrm{~kg} \mathrm{ha}^{-1}$ of the 20-05-20 (N-P-K) mixture. The marandu grass was harvested at 70 days of regrowth and cut to $5 \mathrm{~cm}$ from the ground with the help of a costal brush. The cutting of the Stylo legume, corresponding to the regrowth, was carried out when the plants were in full flowering phase, and also cut to $5 \mathrm{~cm}$ of the ground. After cutting, both forages were chopped in a stationary forage machine in particles of approximately $2 \mathrm{~cm}$. Initially, it was chopped the marandu grass and then the Stylo legume. Afterwards, the forages were weighed, and mixed in appropriate levels to compose the treatments. A $4 \times 2$ factorial arrangement was used, with 4 Stylo legume levels (S) and presence or absence of microbial inoculant (I), in a completely randomized design, with four replications. The levels of Stylo legume were: 0 (control), 10, 20 and 30\% by weight in the natural matter (NM). The Sil All C4® microbial inoculant (Alltech, Araucária, Paraná, Brazil) was applied with a $250 \mathrm{~mL}$ capacity hand sprayer in silages with inoculant treatments. The dosage used was as recommended by the manufacturer. The ensiling of the different grass and legume mixtures was done in experimental silos (plastic buckets) with a capacity of $20 \mathrm{~L}$, equipped with a Bunsen valve adapted in their lids to allow gases to escape from the fermentation. At the bottom of the silos were placed $4 \mathrm{~kg}$ of dry sand in a cloth bag, for further estimation of the effluent production. The silos were weighed at the time of closure and opening, for quantification of gas losses. At the time of closing, all buckets were sealed with adhesive tape and stored in a covered area at room temperature for 60 days. The gases and effluents losses and the dry matter recovery (DMR) were estimated according to techniques described by (Jobim, Nussio, Reis, \& Schmidt, 2007). To measure the pH, $25 \mathrm{~g}$ of silage samples were homogenized in $225 \mathrm{~mL}$ of phosphate buffer (Ringer Solution ${ }^{\circledR}$ ) for one minute in a blender. To obtain the aqueous extract, this mixture was filtered through a Whatman Grade 54 paper filter, and the $\mathrm{pH}$ was immediately measured on a digital $\mathrm{pH}$ meter (DM-23, Digimed). For the determination of the ammonia nitrogen $\left(\mathrm{N}^{-\mathrm{NH}_{3}}\right), 200 \mathrm{~mL}$ of a $2 \mathrm{~N} \mathrm{H}_{2} \mathrm{SO}_{4}$ solution were added to $25 \mathrm{~g}$ of silage that had been stored in a refrigerator for 48 hours. After filtration on filter paper, the $\mathrm{N}-\mathrm{NH}_{3}$ concentration was determined by titration with weak acid according to the methodology described by Bolsen et al. (1992).

For chemical composition analysis (Table 1), approximately $300 \mathrm{~g}$ of silage sample were collected from the plants prior the ensiling and from each experimental silos. The pre-drying of the samples was performed in a convection oven at $55{ }^{\circ} \mathrm{C}$ for 72 hours. After, the grasses were ground on a Willey mill with a $1 \mathrm{~mm}$ sieve and stored in polyethylene plastic vials for subsequent laboratory analyses. The samples were analyzed for DM, ash, crude protein (CP), neutral detergent fiber (NDF) and acid detergent fiber (ADF) according to Detmann et al. (2012).

Table 1. Chemical composition of marandu grass and Stylo legume in nature

\begin{tabular}{lll}
\hline Itens & Marandu grass & Stylo legume \\
\hline Dry Matter (g/kg feed) & 228.3 & 231.5 \\
Ash (g/kg DM) & 87.2 & 79.1 \\
Crude Protein (g/kg DM) & 69.3 & 129.1 \\
Neutral Detergent Fiber (g/kg DM) & 744.2 & 635.9 \\
Acid Detergent Fiber (g/kg DM) & 428.1 & 415.9 \\
\hline
\end{tabular}


The microbial populations were quantified using the following selective cultures for each microbial group: Rogosa agar (Difco), for lactic acid bacteria (LAB) count; violet red bile (Difco) with overlying, for enterobacteria count; and potato dextrose agar, for count of molds and yeasts.

The evaluation of data was performed by an analysis of variance at $5 \%$ significance using the SISVAR program (Ferreira, 2014). For the qualitative factor (inoculant), the F test was used. A regression analysis was performed for the quantitative factor (levels of Stylo legume). The interaction Stylo legume $\times$ inoculant $(\mathrm{S} \times \mathrm{I})$ was deployed when significant at a $5 \%$ probability.

\section{Results and Discussion}

Interaction effect $\mathrm{S} \times \mathrm{I}$ on DM content was observed (Table 2).

Table 2. Mean chemical composition of marandu grass silage with different levels of Stylo legume with or without inoculant

\begin{tabular}{|c|c|c|c|c|c|c|c|}
\hline \multirow{2}{*}{ Inoculant } & \multicolumn{4}{|c|}{ Levels of Stylo legume (\%) } & \multirow{2}{*}{ CV $(\%)$} & \multirow{2}{*}{ Regression equation } & \multirow{2}{*}{$\mathrm{R}^{2}$} \\
\hline & 0 & 10 & 20 & 30 & & & \\
\hline \multicolumn{8}{|c|}{--------- DM (g/kg) ---------- } \\
\hline Without & $215.8 \mathrm{a}$ & $215.1 \mathrm{~b}$ & $219.5 b$ & $234.6 \mathrm{a}$ & \multirow{2}{*}{1.06} & \multirow{2}{*}{$\begin{array}{l}\hat{Y}=21.2115+0.0609 X \\
\hat{Y}=21.4615+0.048525 X\end{array}$} & 0.74 \\
\hline \multirow[t]{2}{*}{ With } & $215.1 \mathrm{a}$ & $218.9 \mathrm{a}$ & $224.1 \mathrm{a}$ & $229.6 b$ & & & 0.99 \\
\hline & - & Ash $(\mathrm{g}$ & (g DM) & - n----- & & & \\
\hline Without & 64.4 & 73.3 & 71.2 & 77.2 & \multirow{2}{*}{5.06} & \multirow{2}{*}{$\hat{Y}=6.4615+0.048525 X$} & \multirow{2}{*}{0.71} \\
\hline \multirow[t]{2}{*}{ With } & 68.2 & 75.2 & 77.4 & 73.9 & & & \\
\hline & ------ & $-\mathrm{CP}(\mathrm{g} /$ & g DM) - & - n-- & & & \\
\hline Without & 78.8 & 72.0 & 83.1 & 93.2 & \multirow{2}{*}{7.56} & \multirow{2}{*}{$\hat{\mathrm{Y}}=7.376+0.0551 \mathrm{X}$} & \multirow{2}{*}{0.87} \\
\hline \multirow[t]{2}{*}{ With } & 73.7 & 80.1 & 84.4 & 90.9 & & & \\
\hline & --- & NDF & (kg DM) & - n--- & & & \\
\hline Without & 707.1 & 702.6 & 660.0 & 624.0 & \multirow{2}{*}{2.34} & \multirow{2}{*}{$\hat{Y}=71.62025-0.265163 X$} & \multirow{2}{*}{0.93} \\
\hline \multirow[t]{2}{*}{ With } & 708.7 & 695.1 & 679.2 & 634.6 & & & \\
\hline & - & ADF & (kg DM) & - & & & \\
\hline Without & 406.2 & 423.6 & 403.4 & 394.8 & \multirow{2}{*}{3.11} & \multirow{2}{*}{$\hat{Y}=40.859563+0.101019 X-0.004934 X^{2}$} & \multirow{2}{*}{0.92} \\
\hline With & 409.2 & 409.4 & 409.1 & 396.0 & & & \\
\hline
\end{tabular}

Note. CV: coefficient of variation. Means followed by different letters in the columns differ $(\mathrm{P}<0.05)$ by the $\mathrm{F}$ test.

There was a linear increase $(\mathrm{P}<0.05)$ in the DM contents with the increase of the levels of Stylo legume in the silages with and without microbial inoculant. These increases were of the order of 0.05 and $0.06 \%$ for each $1 \%$ of Stylo legume added in the silages with and without inoculant, respectively. The increase is due to the higher dry matter content of the Stylo legume in relation to the marandu grass. Similar behavior was observed by (Bureenok, Sisaath, Yuangklang, Vasupen, \& Schonewille, 2016) when evaluating the chemical composition of mixed silage of Stylo legume and Guinea grass (Megathyrsus maximus (Jacq.)).

Evaluating the inoculant effect within levels of Stylo legume, higher values $(\mathrm{P}<0.05)$ of DM were observed in the inoculated silages, containing 10 and $20 \%$ of Stylo legume comparing to the silages without inoculant. With the addition of $30 \%$ of the Stylo legume, a higher DM content was observed for the silage without inoculant. The variations in the DM contents with or without the use of microbial inoculant are possibly due to differences in the predominant microbial populations, since molds and yeast fermentations tend to produce more water than fermentations by lactic acid bacteria (LAB). The main end products of the fermentation carried out by bacteria of the genus Clostridium are butyric acid, water and carbon dioxide $\left(\mathrm{CO}_{2}\right)$, which together can signal high losses (McDonald, Henderson, \& Heron, 1991).

The CP contents were affected $(\mathrm{P}<0.05)$ only by the levels of Stylo legume that increased linearly, with increments of $0.05 \%$ for each 1\% increase in Stylo legume in the silages. This is due to the higher concentration of nitrogen in the legume comparing to the marandu grass. The increase in CP content of the intercropped silages improves the nutritive value of the silages, thus reducing the need for nutrient supplementation in the diet and the 
cost of the feed (Souza, Pereira, Ribeiro, Santos, \& Valadares Filho, 2014). Epifanio et al. (2016) also observed a linear increased in CP contents with addition of Stylo legume in grass silage.

The constituents of the fibrous fraction of the silages were affected only by the levels of Stylo legume. For NDF, there was a decrease of $0.26 \%$ for each $1 \%$ of Stylo legume. The reduction in the NDF contents is due to the lower content of NDF in Stylo legume, with a diluting effect of the fiber with an increasing amount of Stylo legume. The contents of ADF were influenced in a quadratic form, with maximum ADF content $(41.38 \%)$ at the $10.24 \%$ level of Stylo legume. The lower fiber contents in legumes in relation to tropical grasses are explained mainly by the physiological differences between them, being the marandu grass a $\mathrm{C} 4$ specie and the leguminous C3. Differences in fiber content between grass and legume silages were also observed by Leonel et al. (2008) and Silva et al. (2015), this result is an indicative of higher digestibility and, consequently, better nutritive value of the silages with legume.

The effect $(\mathrm{P}<0.05)$ on the $\mathrm{pH}$ value of the silages was observed only for levels of Stylo legume, whose data were adjusted to a quadratic model, estimating a maximum value of 4.16 for the level of $12.25 \%$ of the Stylo legume in the ensiled mass (Table 3).

Table 3. Mean $\mathrm{pH}$, ammonia nitrogen and population of lactic acid bacteria, molds and yeast and enterobacteria in silages of marandu grass with different levels of Stylo legume with or without inoculant

\begin{tabular}{|c|c|c|c|c|c|c|c|c|}
\hline \multirow{2}{*}{ Inoculant } & \multicolumn{4}{|c|}{ Stylo legume levels $(\%)$} & \multirow{2}{*}{ Means } & \multirow{2}{*}{ CV $(\%)$} & \multirow{2}{*}{ Regression equation } & \multirow{2}{*}{$\mathrm{R}^{2}$} \\
\hline & 0 & 10 & 20 & 30 & & & & \\
\hline & \multicolumn{8}{|c|}{------------------ pH ---------------------- } \\
\hline Without & 4.07 & 4.05 & 4.11 & 3.90 & & \multirow{2}{*}{2.78} & \multirow{2}{*}{$\hat{Y}=4.058375+0.017150 X-0.0007 X^{2}$} & \multirow{2}{*}{0.98} \\
\hline With & 4.05 & 4.24 & 4.16 & 3.98 & & & & \\
\hline & \multicolumn{4}{|c|}{---------------- N-NH} & & & & \\
\hline Without & 12.26 & 15.21 & 12.89 & 10.14 & & \multirow{2}{*}{14.20} & \multirow{2}{*}{$\hat{Y}=14.594875-0.116638 X$} & \multirow{2}{*}{0.82} \\
\hline With & 15.60 & 13.24 & 12.44 & 10.99 & & & & \\
\hline & \multicolumn{4}{|c|}{ LAB $\left(\log\right.$ CFU g $\left.{ }^{-1}\right)$} & \multirow{3}{*}{$\begin{array}{l}7.69 \mathrm{~b} \\
7.83 \mathrm{a}\end{array}$} & & & \\
\hline Without & $7.42 b$ & $7.58 \mathrm{a}$ & $7.82 \mathrm{a}$ & $7.96 \mathrm{a}$ & & \multirow{2}{*}{2.05} & \multirow{2}{*}{$\hat{\mathrm{Y}}=7.543+0.01455 \mathrm{X}$} & \multirow{2}{*}{0.94} \\
\hline With & $7.75 \mathrm{a}$ & $7.66 \mathrm{a}$ & $7.90 \mathrm{a}$ & $8.01 \mathrm{a}$ & & & & \\
\hline & \multicolumn{4}{|c|}{-- Molds and yeast $\left(\log \mathrm{CFU} \mathrm{g}^{-1}\right)$-- } & & & & \\
\hline Without & $3.57 \mathrm{a}$ & $2.66 \mathrm{a}$ & $3.21 \mathrm{a}$ & $3.30 \mathrm{a}$ & & \multirow{2}{*}{25.84} & \multirow{2}{*}{$\begin{array}{l}\hat{Y}=3.4755-0.0782 X+0.002525 X^{2} \\
\hat{Y}=1.7905+0.08055 X\end{array}$} & 0.58 \\
\hline \multirow[t]{2}{*}{ With } & $2.04 b$ & $2.30 \mathrm{a}$ & $3.27 \mathrm{a}$ & $4.39 \mathrm{a}$ & & & & 0.94 \\
\hline & \multicolumn{4}{|c|}{-- Enterobacteria $\left(\log\right.$ CFU g $\left.{ }^{-1}\right)--$} & & & & \\
\hline Without & 0.56 & - & - & - & & & & \\
\hline With & - & - & - & - & & & & \\
\hline
\end{tabular}

Note. CV: coefficient of variation. Means followed by different letters in the columns differ $(\mathrm{P}<0.05)$ by the $\mathrm{F}$ test.

It should be noted that, regardless of the level of Stylo legume, the $\mathrm{pH}$ values recorded are indicators of good fermentation for grass and legume silages, according to criteria established by McDonald et al. (1991), even if legumes present higher buffering power in relation to grasses, tending to maintain the $\mathrm{pH}$ at higher values. Value of pH below 4.5 is ideal for legume silages (Ward \& Ondarza, 2008). For Kung Jr. and Shaver (2001), the pH of legume silages with $30 \% \mathrm{DM}$ and perennial temperate grass silage ranges from 4.3 to 4.7. Other studies (Leonel et al., 2008; Souza et al., 2014; Silva et al., 2014) have shown similar values to that observed in the present work for this characteristic.

As observed for $\mathrm{pH}$, the N-NH $\mathrm{N}_{3}$ content was affected only by the levels of Stylo legume, with decreases of $0.11 \%$ per Stylo legume unit added to the ensiled mass. The reduction of the concentration of $\mathrm{N}-\mathrm{NH}_{3}$ with the addition of Stylo legume in the consortium may be related to variations in $\mathrm{pH}$ values, favored by the greater development of LAB. According to McDonald et al. (1991), $\mathrm{pH}$ values are directly related to the concentration of $\mathrm{N}^{-\mathrm{NH}_{3}}$ because proteolytic microorganisms such as enterobacteria and clostridia develop better at higher $\mathrm{pH}$. There was an effect $(\mathrm{P}<0.05)$ of inoculant and level of Stylo legume on the population of LAB. The LAB population was higher $(\mathrm{P}<0.05)$ in the silage inoculated only in the control silage, no difference was observed between silages inoculated or not, in the presence of Stylo legume. There was a linear increase in the LAB population with an 
increase in the levels of Stylo legume. This is possibly due to the higher CP content of the Stylo legume, thus increasing the availability of essential amino acids for the growth of LAB, as verified by Brady (1966).

It was observed an interaction effect $(\mathrm{P}<0.05)$ on the population of molds and yeasts. The molds and yeast populations were higher $(\mathrm{P}<0.05)$ in the silage without inoculant only in the control treatment, and no difference was observed between the silages inoculated with Stylo legume. A linear increase in the molds and yeast populations was observed for the inoculated silages, with an increase of $0.08 \%$ for each addition unit in the Stylo legume. For the silages without inoculant, a quadratic effect was observed, estimating the minimum molds and yeast population of $2.87 \log \mathrm{CFU} \mathrm{g}{ }^{-1}$ with $15.48 \%$ of Stylo legume in the ensiled mass. Value close to this was observed by (Pereira, Rocha, \& Ferreira, 2007) for molds and yeast populations in elephant grass silages $\left(2.80 \log \mathrm{CFU} \mathrm{g}^{-1}\right)$.

The population of enterobacteria was observed only in the control treatment without inoculant, with a mean of $0.56 \log$ CFU g ${ }^{-1}$ of silage. According to (Pahlow, Muck, Driehuis, Oude Elferink, \& Spoelstra, 2003), population of enterobacteria predominates at the beginning of fermentation process, and are subsequently replaced by LAB. Research on silages has shown that the enterobacteria has a great reduction in the population until the $10^{\text {th }}$ day of fermentation, and may or may not disappear until the end of the fermentation process (Pereira et al., 2007; Bernardes, Reis, \& Moreira, 2005).

The gas production was not affected by treatments, registering an average value of $2.91 \%$ DM (Table 4 ). This behavior is possibly due to the close values of DM and microbial populations of the silages. The production of gas in the silage is the result of secondary fermentations carried out by enterobacteria, clostridia and aerobic microorganisms, which develop better in medium with low DM content (Pahlow et al., 2003). Zopollatto, Daniel, and Nussio (2009) in a review article about the use of microbial additives and aspects of silage in Brazil, found values of gas losses in grasses varying from 2.4 to $8.5 \% \mathrm{DM}$, with an average of $4.7 \% \mathrm{DM}$.

Table 4. Mean loss by gas and effluent, and dry matter recovery of marandu grass silage with different levels of Stylo legume with or without inoculant

\begin{tabular}{|c|c|c|c|c|c|c|c|}
\hline \multirow{2}{*}{ Inoculant } & \multicolumn{4}{|c|}{ Stylo legume levels (\%) } & \multirow{2}{*}{ CV (\%) } & \multirow{2}{*}{ Regression equation } & \multirow{2}{*}{$\mathrm{R}^{2}$} \\
\hline & 0 & 10 & 20 & 30 & & & \\
\hline & \multicolumn{4}{|c|}{------- Gas losses (\% DM) -------- } & & & \\
\hline Without & 3.96 & 2.74 & 2.26 & 2.57 & \multirow{2}{*}{45,57} & & \\
\hline \multirow[t]{2}{*}{ With } & 3.60 & 3.12 & 2.45 & 2.58 & & & \\
\hline & \multicolumn{4}{|c|}{-- Effluent losses $\left(\mathrm{kg} \mathrm{t}^{-1}\right)$} & & & \\
\hline Without & $25.84 \mathrm{a}$ & $20.94 \mathrm{a}$ & $12.44 \mathrm{a}$ & $10.85 \mathrm{a}$ & \multirow{2}{*}{23,29} & $\hat{Y}=25.53725-0.534525 X$ & 0,94 \\
\hline \multirow[t]{2}{*}{ With } & $29.64 \mathrm{a}$ & $13.05 b$ & $14.38 \mathrm{a}$ & $14.08 \mathrm{a}$ & & $\hat{\mathrm{Y}}=28.66225-1.675775 \mathrm{X}+0.042738 \mathrm{X}^{2}$ & 0,90 \\
\hline & - D & yatter & ecovery & \%) ---- & & & \\
\hline Without & $93.58 \mathrm{a}$ & $96.35 \mathrm{a}$ & $95.51 \mathrm{a}$ & $97.43 \mathrm{a}$ & \multirow{2}{*}{12,20} & $\hat{\mathrm{Y}}=94.10675+0.107175 \mathrm{X}$ & 0,72 \\
\hline With & $92.81 \mathrm{a}$ & $97.49 \mathrm{a}$ & $97.01 \mathrm{a}$ & $95.15 b$ & & $\hat{Y}=92.998625+0.555738 X-0.016344 X^{2}$ & 0,95 \\
\hline
\end{tabular}

Note. CV: coefficient of variation. Means followed by different letters in the columns differ $(\mathrm{P}<0.05)$ by the $\mathrm{F}$ test.

The effect of the interaction $(\mathrm{P}<0.05)$ on effluent losses and DMR was observed. Evaluating the effect of level of Stylo legume in the inoculant, it was observed a greater loss by effluent in the silage without inoculant in the proportion of $10 \%$ of Stylo legume. The effluent production is one of the loss forms in the nutritive value of the silages, being influenced by the dry matter contents of the plant, type and size of the silo and degree of compaction (Pereira \& Bernardino, 2004). The effluent production decreased linearly $(\mathrm{P}<0.05)$ in the silage without inoculant with the increase in the levels of Stylo legume.

In the presence of inoculant, a minimum effluent loss value equal to $11.43 \mathrm{~kg} \mathrm{t}^{-1} \mathrm{NM}$ was estimated with $20.5 \%$ of Stylo legume. This effect is directly related to the DM content, with a decrease in losses with an increase in DM content. The values found are within the range of 11.5 to $68.5 \mathrm{~kg} \mathrm{t}^{-1} \mathrm{NM}$, recorded by Zapollatto et al. (2009), for silage of tropical grasses. The effect of the interaction $(\mathrm{P}<0.05)$ on DMR was observed. Greater DMR $(\mathrm{P}<0.05)$ was observed in the silage without inoculant with $30 \%$ of Stylo legume and an increased linearly effect was observed with the Stylo legume levels in the absence of inoculant. However, in the silage with inoculant, maximum DMR (97.72\%) was estimated, with 17\% of Stylo legume in the ensiled mass. This is 
possibly due to the increase in the DM content, providing a better fermentation profile and reduction of losses by gases and effluents. The values found in this work for silages containing Stylo legume are higher than the mean value of $92 \%$ reported by Zapollatto et al. (2009) for grass silage. This indicates that legume silage in association with grasses is an alternative to reduce losses and provide a better recovery of dry matter of silages.

\section{Conclusions}

The Stylo legume improves the nutritional quality, the fermentation profile and reduces the losses of silage with marandu grass.

The use of 20 to $30 \%$ of Stylo Legume in the natural matter for the production of mixed marandu grass silage and Stylo Legume results in a greater dry matter recovery of the ensiled mass.

The use of microbial inoculant does not present benefits in relation to chemical composition, fermentation profile and dry matter losses in mixed silages of marandu grass and Stylo Legume.

\section{References}

Bernardes, T. F., Reis, R. A., \& Moreira, A. L. (2005). Fermentative and microbiological profile of marandu-grass ensiled with citrus pulp pellets. Scientia Agricola, 62, 214-220. https://doi.org/10.1590/ S0103-90162005000300003

Bolsen, K. K., Lin, C., Brent, B. E., Feyerherm, A. M., Urban, J. E., \& Aimutis, W. R. (1992). Effect of silage additives on the microbial succession and fermentation process of alfalfa and corn silages. Journal of Dairy Science, 75, 3066-3083. https://doi.org/10.3168/jds.S0022-0302(92)78070-9

Brady, C. J. (1966). The redistribution of nitrogen in silage by lactic-acid-producing bacteria. Australian Journal of Biological Science, 19, 123-130. https://doi.org/10.1071/BI9660123

Bureenok, S., Sisaath, K., Yyangklang, C., K., Vasupen, J., \& Schonewille, T. H. (2016). Ensiling characteristics of silages of Stylo legume (Stylosanthes guianensis), Guinea grass (Panicum maximum) and their mixture, treated with fermented juice of lactic bacteria, and feed intake and digestibility in goats of rations based on these silages. Small Ruminant Research, 134, 84-89. https://doi.org/10.1016/j.smallrumres.2015.12.006

Detmann, E., Souza, M. A., Valadares Filho, S. C, Queiroz, A. C., Berchielli, T. T., Saliba, E. O. S., ... Azevedo, J. A. G. (2012). Métodos para análise de alimentos-INCT_Ciência Animal. Visconde do Rio Branco: Suprema.

Epifanio, P. S., Costa, K. A., Guarnieri, A., Teixeira, D. A. A., Oliveira, S. S., \& Silva, V. R. (2016). Silage quality of Urochloa brizantha cultivars with levels of campo grande Stylosanthes. Acta Scientiarum. Animal Sciences, 38, 135-142. https://doi.org/10.4025/actascianimsci.v38i2.29631

Ferreira, D. F. (2014). Sisvar: A Guide for its Bootstrap procedures in multiple comparisons. Ciência e Agrotecnologia, 38, 109-112. https://doi.org/10.1590/S1413-70542014000200001

Jobim, C. C., Nussio, L. G., Reis, R. A., \& Schmidt, P. (2007). Avanços metodológicos na avaliação da qualidade da forragem conservada. Revista Brasileira de Zootecnia, 36, 101-119. https://doi.org/10.1590/S1516-3598 2007001000013

Kung, L., \& Shaver, R. (2001). Interpretation and use of silage fermentation analysis reports. Focus on Forage, 3, 1-5. Retrieved from http://fyi.uwex.edu/forage/files/2016/10/Fermentation2.pdf.

Leonel, F. P., Pereira, J. C., Costa, M. G., De Marco, P. J., Lara, L. A., Sousa, D. P., \& Silva, C. J. (2008). Consórcio capim-braquiária e soja. Produtividade das culturas e características qualitativas das silagens. Revista Brasileira de Zootecnia, 37, 2031-2040. http://dx.doi.org/10.1590/S1516-35982008001100020

McAllister, T. A., Feniuk, R., Mir, Z., Mir, P., Selinger, L. B., \& Cheng, K.-J. (1998). Inoculants for alfalfa silage: Effects on aerobic stability, digestibility and the growth performance of feedlot steers. Livestock Production Science, 53, 171-181, https://doi.org/10.1016/S0301-6226(97)00150-4.

McDonald, P., Henderson, A. R., \& Heron, S. (1991). The biochemistry of silage (2nd ed., p. 340). Marlow: Chalcombe.

Paciullo, D. S. C., Aroeira, L. J. M., Alvim, M. J., \& Carvalho, M. M. (2003). Características produtivas e qualitativas de pastagem de braquiária em monocultivo e consorciada com estilosantes. Pesquisa Agropecuária Brasileira, 38, 421-426. https://doi.org/10.1590/S0100-204X2003000300012

Pahlow, G., Muck, R. E., Driehuis, F., Oude Elferink, S. J. W. H., \& Spoelstra, S. F. (2003). Microbiology of ensiling. In D. R. Buxton, R. E. Muck, \& J. H. Harrison (Eds.), Silage Science and Technology. American 
Society of Agronomy, Inc., Crop Science Society of America, Inc., Soil Science Society of America, Inc. Publications, Madison, WI.

Pariz, C. M., Costa, C., Crusciol, C. A. C., Meirelles, P. R. L., Castilhos, A. M. de, Andreotti, M., ... Martello, J. M. (2017). Silage production of corn intercropped with tropical forages in an integrated crop-livestock system with lambs. Pesquisa Agropecuária Brasileira, 52, 54-62. https://doi.org/10.1590/s0100-204x2017 000100007

Pereira, O. G., \& Bernardino, F. S. (2004). Controle de efluentes na produção de silagem. Simpósio sobre manejo estratégico da pastagem (pp. 509-545). Anais... Viçosa.

Pereira, O. G., Rocha, K. D., \& Ferreira, C. L. de L. F. (2007). Composição química, caracterização e quantificação da população de microrganismos em capim-elefante cv. Cameroon (Pennisetum purpureum, Schum.) e suas silagens. Revista Brasileira de Zootecnia, 36, 1742-1750. https://dx.doi.org/10.1590/S151635982007000800006

Santos, A. O., Ávila, C. L. S., Pinto, J. C., Carvalho, B. F., Dias, D. R., \& Schwan, R. F. (2016). Fermentative profile and bacterial diversity of corn silages inoculated with new tropical lactic acid bacteria. Jornal of Applied Microbiology, 120, 266-279. https://doi.org/10.1111/jam.12980

Silva, T., Pereira, O., Agarussi, M., da Silva, V., da Silva, L., Cardoso, L., Ribeiro, K., \& Valadares Filho, S. C. (2015). Stylosanthes cv. Campo Grande silage with or without concentrate in sheep diets: Nutritional value and ruminal fermentation. Small Ruminant Research, 126, 34-39. https://doi.org/10.1016/j.smallrumres.20 15.03.011

Souza, W. F., Pereira, O. G., Ribeiro, K. G., Santos, S. A., \& Valadares Filho, S. C. (2014). Intake, digestibility, nitrogen efficiency, and animal performance of growing and finishing beef cattle fed warm-season legume (Stylosanthes capitata plus Stylosanthes macrocephala) silage replacing corn silage. Journal of Animal Science, 92, 4099-4107. https://doi.org/10.2527/jas.2013-7480

Ward, R. T., \& de Ondarza, M. B. (2008). Fermentation analysis of silage: use and interpretation. Retrieved from http://fermentation-silage-nfmp-oct-2008(3).pdf

Zopollatto, M., Daniel, J. L. P., \& Nussio, L. G. (2009). Aditivos microbiológicos em silagens no Brasil: Revisão dos aspectos da ensilagem e do desempenho de animais. Revista Brasileira de Zootecnia, 38, 170-189. https://doi.org/10.1590/S1516-35982009001300018

\section{Abbreviations}

I: microbial inoculant; S: Stylo legume level; SxI: Interation between Stylo legume and microbial inoculants; DM: dry matter; CP: crude protein; NDF: neutral detergent fiber; ADF: acid detergent fiber; $\mathrm{N}^{-N_{3}}$ : ammonia nitrogen; LAB: lactic acid bacteria; DMR: dry matter recovery.

\section{Copyrights}

Copyright for this article is retained by the author(s), with first publication rights granted to the journal.

This is an open-access article distributed under the terms and conditions of the Creative Commons Attribution license (http://creativecommons.org/licenses/by/4.0/). 